American Journal of Biochemistry and Biotechnology 1 (3): 167-172, 2005

ISSN 1553-3468

(c) 2005 Science Publications

\title{
Molecular Characterization of Tospovirus Transmitting Thrips Populations from India
}

\author{
Rang Lal Meena, T. Ramasubramanian, S. Venkatesan and S. Mohankumar \\ Department of Plant Molecular Biology and Biotechnology \\ Tamil Nadu Agricultural University, Coimbatore - 641003, Tamil Nadu, India
}

\begin{abstract}
The presence of Tospovirus in thrips vector, Scirtothrips dorsalis has been detected for the first time in India using RT- PCR analysis. Similarly RT-PCR analysis with GBNV infected tomato leaves also resulted in the amplification of cDNA corresponding to the $\mathrm{N}$ gene (approximately $830 \mathrm{bp}$ ) of Coimbatore isolate. Dendrogram constructed on the basis of RAPD similarity matrix revealed that $S$. dorsalis population from tomato, groundnut and chillies had atleast $75 \%$ similarity while; only $50 \%$ similarity existed between the Frankliniella schultzei populations from cowpea and sunnhemp. Thrips tabaci from cotton was distantly related with $S$. dorsalis and Frankliniella schultzei with lowest similarity indices (less than 0.464). This was also confirmed by the ISSR analysis with the same six thrips populations. It is evident from the present study that RAPD markers were more informative than ISSR in differentiating host-associated populations of thrips.
\end{abstract}

Key words: Tospovirus, Scirtothrips dorsalis, Thrips tabaci, Frankliniella schultzei, ISSR, RAPD, RTPCR

\section{INTRODUCTION}

Tospoviruses belonging to the family Bunyaviridae $^{[1]}$ are one among the ten most devastating plants viruses ${ }^{[2]}$ with a host range of over 1050 species $^{[3]}$. Tospoviruses represent the only plant virus group that is biologically transmitted by thrips ${ }^{[4]}$. Indeed, Tospoviruses are not known to exist in crops or in nature in the absence of thrips ${ }^{[5]}$. Only ten species of thrips (Thysanoptera: Thripidae) were reported as vectors of tospoviruses out of more than 5000 species recorded worldwide ${ }^{[6]}$. Thus less than 0.2 per cent of the Thysanoptera species were known to be associated with Tospoviruses, and there was no evidence that many more thrips species are likely to be implicated ${ }^{[7]}$. Only five of the 160 described species of Frankliniella, four of the 280 species of the genus Thrips and just one of the 90 species of Scirtothrips were reported as vectors of Tospoviruses ${ }^{[6,7]}$. Although the dependency of Tospoviruses on thrips is so strong, it is surprising that so little attention has been paid to characterize the Tospovirus transmitting thrips populations in India. It has already been suggested that molecular tools need to be exploited to discriminate populations differing in important traits such as virus transmission ${ }^{[8]}$. PCR based techniques have already been applied in the field of intra- and inter-specific polymorphism in Thysanoptera species $^{[9-11]}$ and suitable DNA polymorphism was detected to distinguish populations originating from geographically different locations ${ }^{[11]}$. However, the use of molecular markers in the field of thrips vectors is scanty. Hence molecular markers viz., RAPD (Random Amplified Polymorphic DNA) and
ISSR (Inter Simple Sequence Repeat) were employed to characterize the Tospovirus transmitting thrips populations collected from the state of Tamil Nadu, India.

\section{MATERIALS AND METHODS}

Sampling sites: Three different species of thrips namely, Frankliniella schultzei (Trybom), Scirtothrips dorsalis Hood and Thrips tabaci Lindeman found associated with the Tospovirus transmission in six different host plants viz., groundnut, tomato, chillies, cowpea, sunnhemp, and cotton were collected in and around Coimbatore, Tamil Nadu, India.

DNA extraction: The DNA was extracted from 100 individuals representing each population by CTAB (hexadecyl trimethyl ammonium bromide) procedure ${ }^{[12]}$ as modified by Mendel et $\mathrm{al}^{[13]}$. The quantity and quality of the isolated DNA were determined using DyNA Quant 200 - Fluorimeter and $0.8 \%$ agarose gel stained with ethidium bromide.

\section{PCR amplification}

RAPD analysis: The RAPD analysis was performed with ten decamer primers supplied by Operon Technologies Inc., California, USA (Table 1). The PCR amplification was carried out in $10 \mu \mathrm{l}$ reaction mixture containing $25 \mathrm{ng}$ genomic DNA, $8 \mathrm{mM}$ dNTPs, 10Xassay buffer, $0.2 \mu \mathrm{M}$ primer and $0.4 \mathrm{U}$ Taq DNA polymerase. Amplification was performed in PTC$100^{\mathrm{TM}}$ thermocycler (MJ Research Inc., USA) programmed as one cycle of initial denaturation at $94^{\circ} \mathrm{C}$

Corresponding Author: S. Mohankumar, Department of Plant Molecular Biology and Biotechnology, Tamil Nadu Agricultural University, Coimbatore - 641003, Tamil Nadu, India 
for $2 \mathrm{~min}$; 40 cycles each of $94^{\circ} \mathrm{C}$ for 1 min., $47-55^{\circ} \mathrm{C}$ for $1 \mathrm{~min}$., $72^{\circ} \mathrm{C}$ for $1 \mathrm{~min}$; and final extension at $72^{\circ} \mathrm{C}$ for $7 \mathrm{~min}$. The PCR products were separated in $1.5 \%$ agarose gel electrophoresis.

ISSR analysis: ISSR analysis was performed with five ISSR primers supplied by Sigma Genosys Ltd., Bangalore (Table 1). PCR amplification was carried out in $15 \mu \mathrm{l}$ reaction volume containing $20-30 \mathrm{ng}$ of genomic DNA, $0.80 \mu \mathrm{M}$ of primer, $0.66 \mathrm{mM}$ each of dATP, dGTP, dCTP and dTTP, $1.5 \mathrm{mM}$ assay buffer and 0.03 units of Taq DNA polymerase. Amplification was done using a PTC-100 ${ }^{\mathrm{TM}}$ thermocycler (MJ Research Inc.,) programmed for initial denaturation at $94^{\circ} \mathrm{C}$ for $5 \mathrm{~min}, 40$ cycles of $1 \mathrm{~min}$ denaturation at $94^{\circ} \mathrm{C}, 1 \mathrm{~min}$ annealing at respective temperatures and 2 min extension at $72{ }^{\circ} \mathrm{C}$ and final extension at $72{ }^{\circ} \mathrm{C}$ for 5 min. The PCR products were electrophoresed in a 4 per cent denaturing poly acrylamide gel electrophoresis $^{[14]}$ and resolved by silver staining procedure $^{[15]}$.

Analysis of PCR amplification profiles: Clearly resolved, unambiguous polymorphic bands were scored visually for their presence or absence in each RAPD as well as ISSR primer. The scores were obtained in the form of a matrix with ' 1 ' and ' 0 ', which indicate the presence and absence of bands respectively. The genetic diversity among the thrips populations were evaluated by calculating the Jaccard's Similarity Coefficient ${ }^{[16]}$ using the NTSYS-PC software, version $2.0^{[17]}$ and dendrogram was constructed by the Unweighted Pair-Group method (UPGMA).

\section{ISOLATION OF RNA AND DETECTION OF TOSPOVIRUS}

Isolation of total RNA: RNA from $S$. dorsalis and GBNV (Groundnut Bud Necrosis Virus) infected tomato leaves was extracted using TRI Reagent (Sigma-Aldrich, USA) as per the protocol described by Chomczynski and Sacchi ${ }^{[18]}$ with necessary modifications. Isolated total RNA was used as a template for amplification in the reverse transcription and polymerase chain reaction (RT -PCR)

PCR amplification: RT-PCR ${ }^{[19]}$ was performed with the degenerate primers TTACAATTCCAGCGAAGGACC 3, and 5'ATGTCTAACGTT/CAAGCAG/ACTC 3'- NCBI Accession \# 515817 and PB 27809) to amplify GBNV $\mathrm{N}$ gene from first strand cDNA as described by Sambrook et al. ${ }^{[14]}$ with a few modifications. PCR was carried out in $50 \mu \mathrm{l}$ reaction mixture containing $2.0 \mu \mathrm{l}$ of first strand cDNA, $5.0 \mu$ of $10 \mathrm{X}$ PCR buffer $(10 \mathrm{~m}$ M Tris- $\mathrm{HCl} \mathrm{pH} 9.0,50 \mathrm{mM} \mathrm{KCl}, 1.5 \mathrm{mM} \mathrm{MgCl}_{2}$, $0.001 \%(\mathrm{w} / \mathrm{v})$ gelatin), $20 \mathrm{mM}$ each of dNTPs, 100ng each of forward and reverse primers and 1.5 U of Taq
Table 1: List of RAPD and ISSR primers used for genetic diversity analysis

\begin{tabular}{ll}
\hline Primer & Sequence $\left(5^{\prime}-{ }^{\prime}{ }^{\prime}\right)$ \\
RAPD Primers & \\
\hline OPA 01 & CAGGCCCTTC \\
OPA 07 & GAAACGGGTG \\
OPA 08 & GTGACGTAGG \\
OPA 13 & CAGCACCCAC \\
OPC 02 & GTGAGGCGTC \\
OPC 08 & TGGACCGGTG \\
OPC 15 & GACGGATCAG \\
OPE 04 & GTGACATGCC \\
OPE 08 & TCACCACGGT \\
OPE 15 & ACGCACAACC \\
ISSR Primers & \\
ISSR 01 & ATATATATATATATAT T \\
ISSR 02 & AT ATATATATATATATG \\
ISSR 03 & ATATATATATATATATC \\
ISSR 05 & TATATATATATATATAC \\
ISSR 10 & GAGAGAGAGAGAGAGAT \\
\hline
\end{tabular}

DNA polymerase (Bengalore Genei Pvt. Ltd., Bangalore, India) in PTC-100 ${ }^{\mathrm{TM}}$ thermal cycler (MJ Research, Inc., USA) with temperature profile of initial denaturation at $94^{\circ} \mathrm{C}$ for 2 min., 40 cycles of melting at $94^{\circ} \mathrm{C}$ for $30 \mathrm{sec}$, annealing at $58^{\circ} \mathrm{C}$ for $1 \mathrm{~min}$, synthesis at $72^{\circ} \mathrm{C}$ for $1 \mathrm{~min}$ followed by final extension at $72^{\circ} \mathrm{C}$ for $10 \mathrm{~min}$. The amplified product was electrophoresed on $1.0 \%$ agarose gel.

\section{RESULTS AND DISCUSSION}

Survey at the experimental fields of Tamil Nadu Agricultural University revealed that there were two different species of thrips viz., $F$. schultzei and $S$. dorsalis, found associated with GBNV transmission in different host plants. F. schultzei was found to be the vector of GBNV in cowpea and sunnhemp whereas, $S$. dorsalis in groundnut, tomato and chillies.

RAPD analysis: DNA based molecular marker technique is a powerful method in genetic diversity analysis of insect pests $^{[20]}$. The major advantage of the PCR based marker systems is the generation of fragments from both single and multi loci. All the ten RAPD primers used in this study generated scorable PCR products by amplifying the template DNA with Taq polymerase. Of the ten primers tested, the number of RAPD products generated was higher for the primers OPA 08 (Fig. 1) and OPE 15 (17), while lowest number of markers (4) were produced by the primer, OPA 01 (Table 2). Such a wide variation in the number of markers produced by these arbitrary primers may be attributed to the differences in the binding sites throughout genome of the genotypes studied. Generation of higher number of markers or alleles in the present study indicated the higher amount of genetic diversity among different populations of Tospovirus transmitting thrips. Among the ten primers, nine primers showed 100 per cent polymorphism except OPE $08(83.3 \%)$. RAPD primers produced the highest 
Am. J. Biochem. \& Biotech. 1 (3): 167-172, 2005

Table 2: Total number of markers and per cent polymorphism detected using RAPD primers

\begin{tabular}{lcccc}
\hline Primer & Max. number of markers generated & Polymorphic markers & Monomorphic markers & Polymorphism $(\%)$ \\
\hline OPA 01 & 4 & 4 & - & 100 \\
OPA 07 & 12 & 12 & - & 100 \\
OPA 08 & 17 & 17 & - & 100 \\
OPA 13 & 10 & 10 & - & 100 \\
OPC 02 & 12 & 12 & - & 100 \\
OPC 08 & 14 & 14 & - & 100 \\
OPC 15 & 9 & 9 & - & 100 \\
OPE 04 & 15 & 15 & 1 & 83.3 \\
OPE 08 & 6 & 5 & - & 100 \\
OPE 15 & 17 & 17 & - & \\
\hline
\end{tabular}

Table 3: $\quad$ Similarity index values among six thrips populations obtained through RAPD-PCR analysis

\begin{tabular}{|c|c|c|c|c|c|c|}
\hline & $\begin{array}{l}\text { S. dorsalis } \\
\text { (tomato) }\end{array}$ & $\begin{array}{l}\text { T. tabaci } \\
\text { (cotton) }\end{array}$ & $\begin{array}{l}\text { F. schultzei } \\
\text { (cowpea) }\end{array}$ & $\begin{array}{l}\text { S. dorsalis } \\
\text { (chillies) }\end{array}$ & $\begin{array}{l}\text { S. dorsalis } \\
\text { (groundnut) }\end{array}$ & $\begin{array}{l}\text { F. schultzei } \\
\text { (sunnhemp) }\end{array}$ \\
\hline S. dorsalis (tomato) & 1.000 & & & & & \\
\hline T. tabaci (cotton) & 0.463 & 1.000 & & & & \\
\hline F.schultzei (cowpea) & 0.116 & 0.096 & 1.000 & & & \\
\hline S. dorsalis (chillies) & 0.783 & 0.402 & 0.137 & 1.000 & & \\
\hline S. dorsalis (groundnut) & 0.803 & 0.423 & 0.115 & 0.759 & 1.000 & \\
\hline F. schultzei (sunnhemp) & 0.216 & 0.227 & 0.500 & 0.188 & 0.198 & 1.000 \\
\hline
\end{tabular}

Table 4: Total number of markers and per cent polymorphism detected using ISSR primers

\begin{tabular}{|l|l|l|l|l|}
\hline Primer & Max. number of markers generated & Polymorphic markers & Monomorphic markers & Polymorphism (\%) \\
\hline ISSR 02 & 12 & 11 & 1 & 91.7 \\
\hline ISSR 03 & 11 & 10 & 1 & 90.9 \\
\hline ISSR 05 & 16 & 16 & - & 100 \\
\hline ISSR 09 & 11 & 7 & 4 & 63.6 \\
\hline ISSR 10 & 16 & 7 & 9 & 43.8 \\
\hline
\end{tabular}

Table 5: $\quad$ Similarity index values among six thrips populations obtained through ISSR-PCR analysis

\begin{tabular}{lllllll}
\hline & $\begin{array}{l}\text { S.dorsalis } \\
\text { (tomato) }\end{array}$ & $\begin{array}{l}\text { T. tabaci } \\
\text { (cotton) }\end{array}$ & $\begin{array}{l}\text { F. schultzei } \\
\text { (cowpea) }\end{array}$ & $\begin{array}{l}\text { S. dorsalis } \\
\text { (groundnut) }\end{array}$ & $\begin{array}{l}\text { F. schultzei } \\
\text { (sunnhemp) }\end{array}$ & $\begin{array}{l}\text { S. dorsalis } \\
\text { (chillies) }\end{array}$ \\
\hline S.dorsalis (tomato) & 1.000 & & & & & \\
T. tabaci (cotton) & 0.466 & 1.000 & & & & \\
F. schultzei (cowpea) & 0.500 & 0.444 & 1.000 & & & \\
S. dorsalis (groundnut) & 0.900 & 0.410 & 0.492 & 1.000 & & \\
F. schultze (sunnhemp) & 0.596 & 0.464 & 0.826 & 0.559 & 1.000 & 1.000 \\
S. dorsalis (chillies) & 0.979 & 0.458 & 0.492 & 0.920 & 0.586 & \\
\hline
\end{tabular}
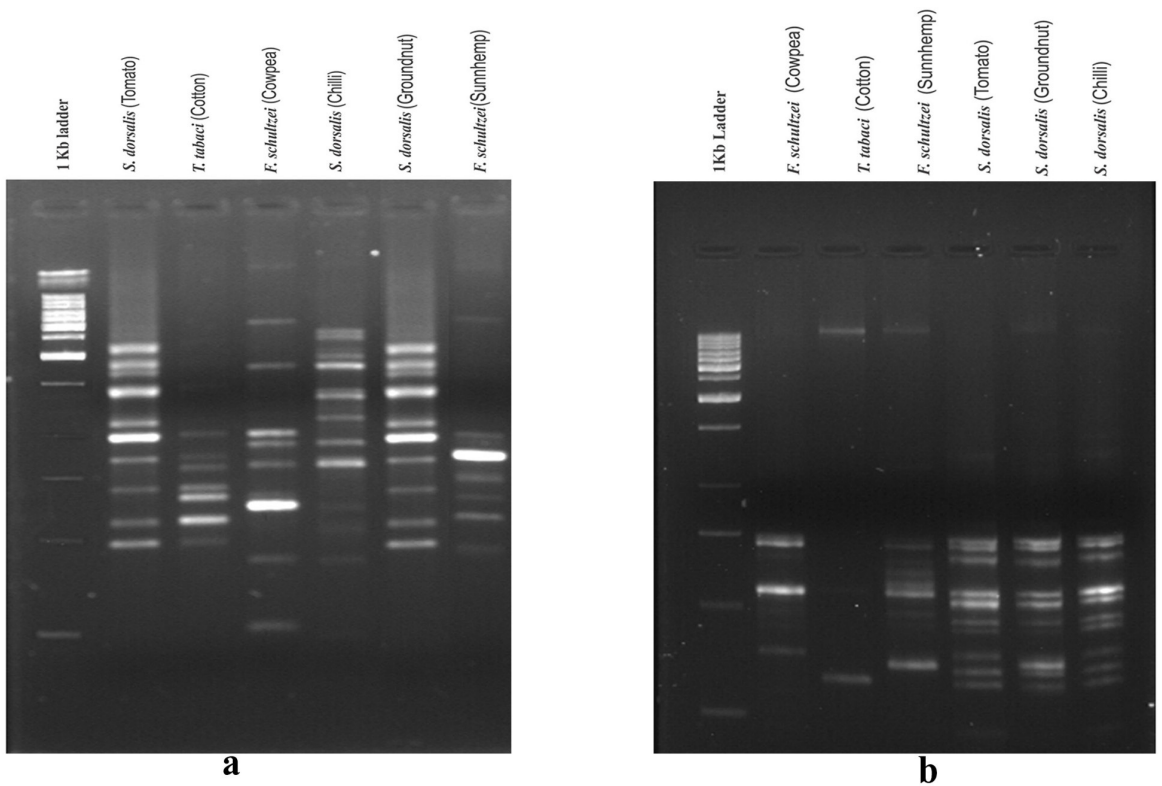

Fig. 1: Molecular polymorphism among six thrips populations after PCR amplification with a) OPA 08 b) OPC 08 


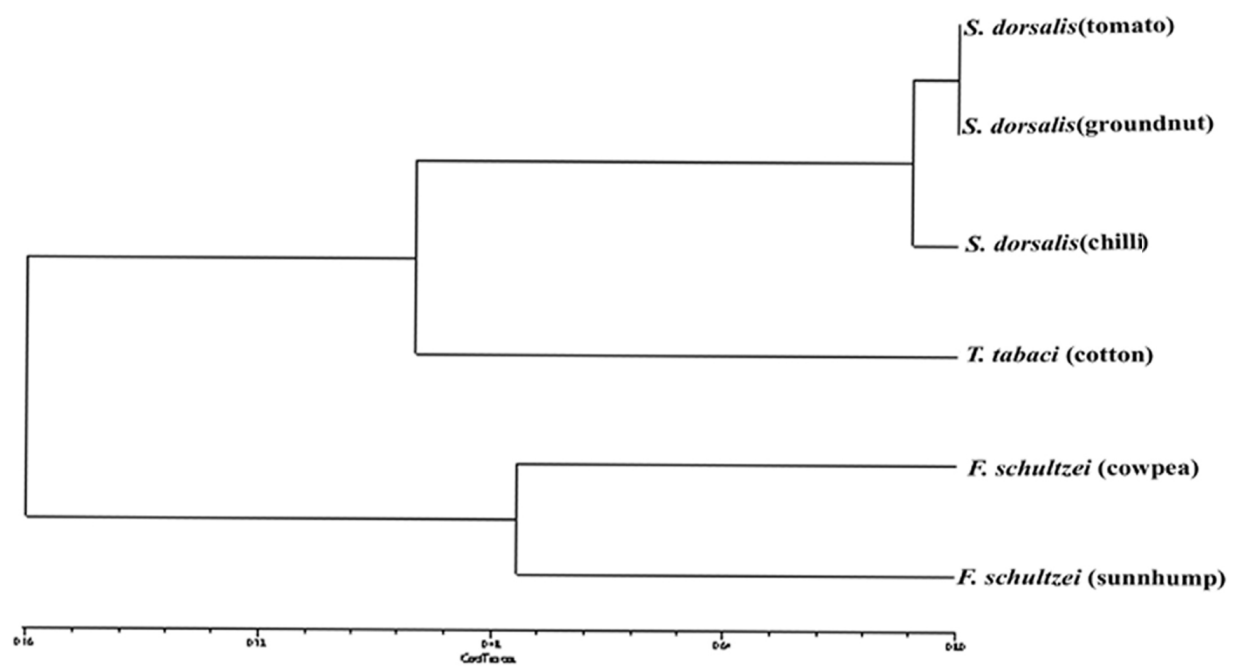

Fig. 2: Cluster dendrogram showing the relationship among wix thrips populations using RAPD primers
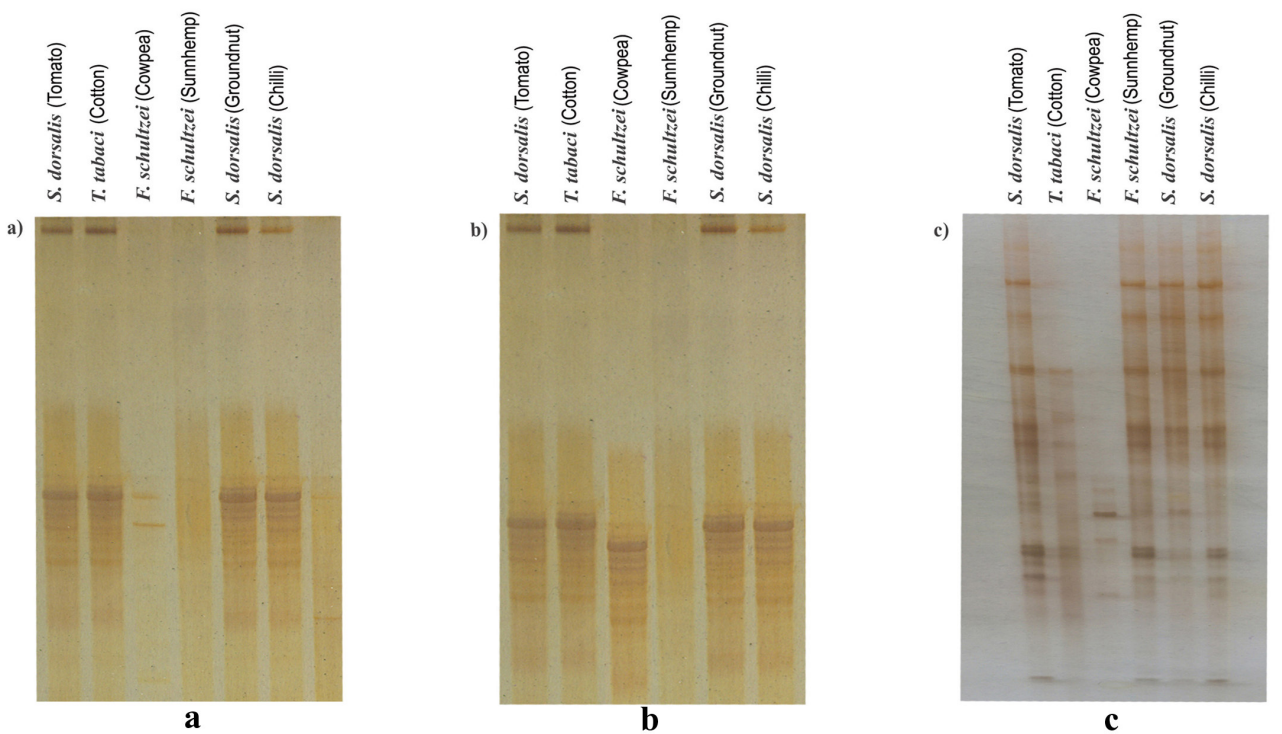

Fig. 3: Molecular polymorphism generated among six thrips populations using a) ISSR 02 b) ISSR 03 c) ISSR 10

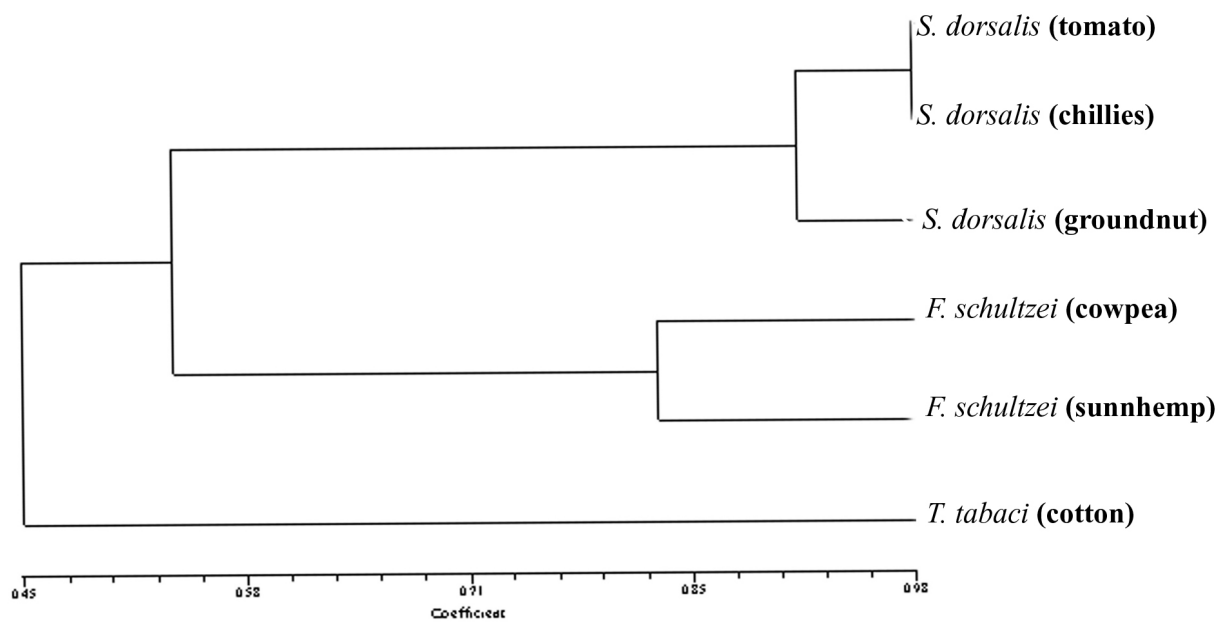

Fig. 4: Cluster dendrogram showing the relationship among six thrips populations using ISSR primers 


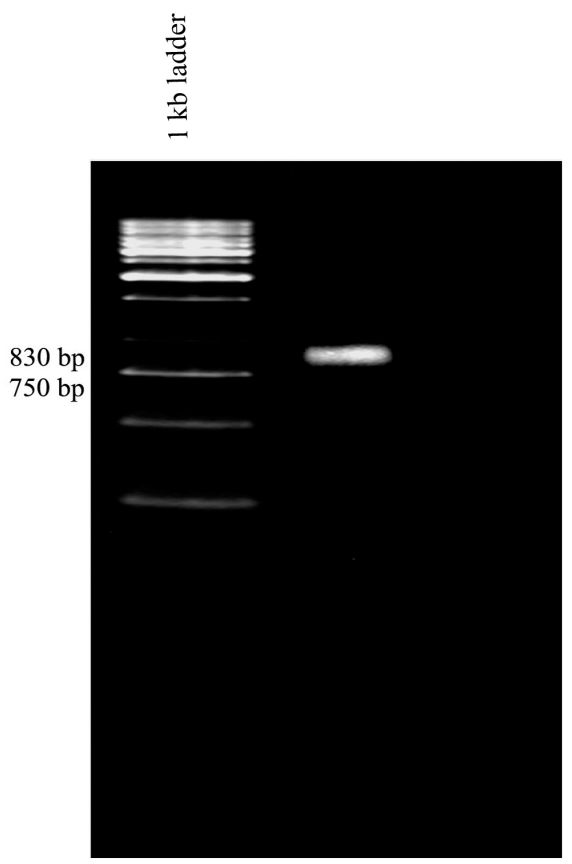

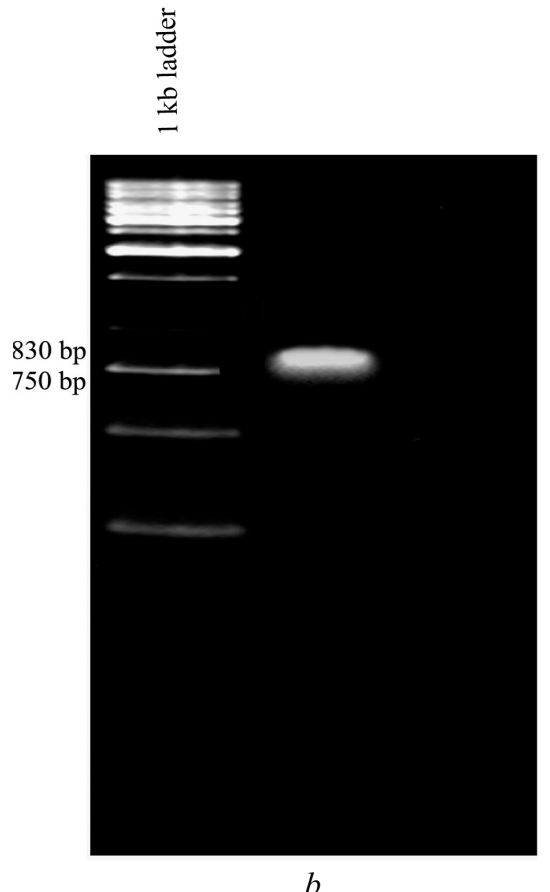

$b$

Fig. 5: Amplification of cDNA through RT-PCR from a) infected tomato plant b) S. dorsalis

number of markers, because these primers scan the whole genome at random. The similarity index values obtained for each pair wise comparison among the six thrips populations based on 116 RAPD markers ranged from 0.096 to 0.803 (Table 3). S. dorsalis from tomato and groundnut showed the highest similarity index $(0.803)$ followed by $S$. dorsalis from tomato and chillies (0.783). T. tabaci population showed less similarity with other two thrips species $(9.6-42.3 \%)$. The RAPD marker system distinguished the different genera into different clusters as expected since they were morphologically and genetically well differentiated. From dendrogram it could be deduced that $S$. dorsalis population from different hosts had atleast $75 \%$ similarity while, only $50 \%$ similarity existed between the F. schultzei population from cowpea and sunnhemp (Fig. 2). This might be the host-induced genetic variation as observed in thrips and other polyphagous insect pests such as Helicoverpa armigera Hubner ${ }^{[21,22]}$. The establishment of this type of diversity has to be checked again by using other marker systems such as ISSR and SSR, because RAPD scans the whole genome, whereas SSR and ISSR search for specific sites in the genome. Since SSR markers are not available, the six thrips populations were again analysed using ISSR markers.

ISSR analysis: The ISSR primers generated a total of 66 markers and the maximum numbers of markers were generated by ISSR 05 and ISSR 10 (16) (Table 4). Among the five primers tested, the highest per cent polymorphism was observed in ISSR 05 (100\%) while the lowest was in ISSR $10(43.8 \%)$ (Fig. 3). The similarity index values obtained for each pair wise comparison among the six thrips populations ranged from 0.410 (between $T$. tabaci from cotton and $S$. dorsalis from groundnut) to 0.979 (between $S$. dorsalis populations from tomato and chillies) (Table 5). $S$. dorsalis populations from different hosts had the highest similarity index (0.900 - 0.979), while T. tabaci, from cotton showed the lowest similarity indices (less than 0.464) with other populations. Dendrogram constructed on the basis of ISSR similarity matrix clearly indicated that the $T$. tabaci from cotton was distantly related with the remaining populations (Fig. 4). The present study, as well as those of others ${ }^{[9-11,21]}$ clearly established the utility of molecular markers such as RAPD and ISSR in assessing the genetic diversity among the host-associated populations. It is evident from the present study that RAPD markers were more informative than ISSR in differentiating host-associated populations of different genera.

Detection of Tospovirus in tomato and $S$. dorsalis: Tospoviruses replicate in their thrips vectors, thus the insects not only spread the virus but also serve as a virus host ${ }^{[23]}$. RT-PCR assay for the detection of Tospovirus was previously employed by several workers in crop plants as well as in vectors ${ }^{[24-26]}$. In the present investigation the presence of Tospovirus was detected in $S$. dorsalis for the first time from India using RT- PCR analysis. Similarly RT-PCR analysis with GBNV infected tomato leaves also resulted in the amplification of cDNA corresponding to the $\mathrm{N}$ gene (approximately $830 \mathrm{bp}$ ) of the Coimbatore isolate of GBNV (Fig. 5). This confirms that the virus present in 
tomato and $S$. dorsalis is GBNV, the type species of the genus Tospovirus in India.

\section{REFERENCES}

1. Van Regenmortel, M.H.V., C.M. Fauquet, D.H.L. Bishop, E.B. Carstens, M.K. Ester, S.M. Lemon, J. Manioff, M.A. Mayo, D.J. McGeoch, D.J. Pringle and R.B. Wickner, 2000. Virus Taxonomy. Seventh Report on the International Committee on Taxonomy of Viruses. Academic Press, San Diego, pp: 1162.

2. Goldbach, R.W. and D. Peters, 1994. Possible causes of the emergence of Tospovirus diseases. Sem. Virol., 5: 113-120.

3. Peters, D., 1998. An Updated List of Plant Species Susceptible to Tospoviruses. In: Recent Progress in Tospovirus and Thrips Research, (eds. D. Peters and R.W. Goldbach). Wageningen Agricultural University, Wageningen, the Netherlands, pp: 107-110.

4. Chatzivassiliou, E.K., I. Livieratos, G. Jenser and N.I. Katis, 2000. Ornamental plants and thrips populations associated with tomato spotted wilt virus in Greece. Phytoparasitica, 28: 257-264.

5. Mound, L.A., 1996. The Thysanoptera vector species of tospoviruses. Acta Horticulturae, 431: 298-309.

6. Ullman, D.E., J.L. Sherwood and T.L. German, 1997. Thrips as Vectors of Plant Pathogens. In: Thrips as Crop Pests, (ed. T. Lewis). Cab Intl., pp: 539-565.

7. Mound, L.A., 2002. So many thrips - So few Tospoviruses? Thrips and Tospoviruses: Proc. Seventh Intl. Symp. on Thysanoptera, 1-8, July, 2001, Reggio, Calabria, Italy.

8. Wijkamp, I., N. Almarza, R.W. Goldbach and D. Peters, 1995. Distinct level of specificity in thrips transmission of tospoviruses. Phytopathology, 85: 1069 -1074.

9. Cenis, J.L. and F. Beitia, 1994. Aplicacion de la tecnica RAPD-PCR (and polimorfico amplificada al azar) a la identificacion de insectos. Investigacion Agraria: Produccion y Protection Vegetables, 9: 289297.

10. Klein, M. and R. Gafni, 1996. Morphological and molecular variations in thrips populations collected on onion plants in Israel. Folia Entomologica Hungarica, 57: 57-59.

11. Kraus, M., G. Schreiter and G. Moritz, 1999. Moleculargenetic Studies of Thrips Species In: (eds. G. Vierbergen, I. Tunc). Proc. Sixth International Symp. Thysanoptera. 27, April- May 1998, Antalya, Turkey, pp: 77-80.

12. Doyle, J.J. and J.L. Doyle, 1990. Isolation of plant DNA from fresh tissue. Focus, 12: 13-15.

13. Mendel, Z., D. Nestel and R. Gafni, 1994. Examination of the origin of the israeli population of the 12.Matsucoccus josephi (Homoptera: Matsucoccidae) using random amplified polymorphic DNA-polymerase chain reaction. Ann. Entomol. Soc. Am., 87: 165-169.
14. Sambrook, J., E.F. Frotsch and T. Maniatis, 1989. Molecular Cloning. A Laboratory Manual. 2nd Edn. Cold Spring Harbour, New York.

15. Panaud, O., X.L. Chen and S.R. McCouch, 1996. Development of microsatellite markers and characterization of simple sequence length polymorphism (SSLP) in rice (Oryza sativa L.). Mol. Gen. Genet., 252: 597-607.

16. Jaccard, P., 1908. Nouvelles Recherches Sur La Distribution Florale. Bull. Soc. Vaud. Sci. Nat., 44: 223-270.

17. Rohlf, F.J., 1998. NTSYS-PC: Numerical taxonomy and multivariate analysis system version 2.0 Department of Ecology and Evolution. State University of New York.

18. Chomczynski, P. and N. Sacchi, 1987. Single- step method of RNA isolation by acid guanidinium thiocyanate-phenol-chloroform extraction. Anal. Biochem., 162: 156-159.

19. Pappu, S.S., R. Brand, H.R. Pappu, E.P. Rybicki, K.H. Gough, M.J. Frenkel and C.L. Niblett, 1993. A polymerase chain reaction method adopted for selective amplification and cloning of 3-sequences of potyviral genomes: Application to dasheen mosaic virus. J. Virol. Methods, 41: 9-20.

20. Loxdale, H.D. and G. Lushai, 1998. Molecular markers in entomology. Bull. Entomol. Res., 88: 577-600.

21. Brunner, P.C., E.K. Chatzivassiliou, N.I. Katis and J.E. Frey, 2004. Host-Associated Genetic dfferentiation in Thrips tabaci (Insecta: Thysanoptera), as dtermined from mtDNA sequence data. Heredity, 93: 364 -370.

22. Scott, K.D., K.S. Wilkinson and M.A. Merritt, 2003. Genetic shifts in Helicoverpa armigera (Hubner) (Lepidoptera: Noctuidae) over a year in the Dawson/Callide Valleys. Australian J. Agril. Res., 54: 739-744.

23. Van de Wetering, F., R. Goldbach and D. Peters, 1996. Tomato spotted wilt tospovirus ingestion by first instar larvae of Frankliniella Occidentalis is a prerequisite for transmission. Phytopathology, 86: 900-905.

24. Mumford, R.A., I. Barker and K.R. Wood, 1994. The detection of tomato spotted wilt virus using the polymerase chain reaction. J. Virol. Methods, 46: 303-311.

25. Thien, H.X, A.I. Bhat and R.K. Jain, 2003. Mungbean necrosis disease caused by a strain of groundnut bud necrosis virus. Indian Phytopath., 56: 54-60.

26. Umamaheswaran, K., R.K. Jain, A.I. Bhat and Y.S. Ahlawat, 2003. Biological and molecular characterization of a tospovirus isolate from tomato and its relationship with other tospoviruses. Indian Phytopath., 56: 168-173. 